\section{APPROACHES TO THE DEVELOPMENT OF CRITICAL ANALYSIS IN THE UNIVERSITY : THE IMPACT OF CULTURE}

\section{Zane Ma Rhea ${ }^{1}$}

When a wise one, established well in virtue, Develops conciousness and understanding, One succeeds in distangling this tangle...

( Samyutta Nikiyai,13)

Correct knowledge can be arrived at only leading from the matter to conciousness and then back to matter...

(Mao Zedong, 1966,p.2)

\section{Introduction}

This chapter offers a discussion about 'critical analysis' looking particularly at its importance within Thai and Australian universities, and focuses on the contentious discussions about the capacity of 'Asians' to think and analyse critically. The central focus is how the skill of critical analysis might be located within the broader model of supervision of higher degree work at university. In particular, closer examination is made of the postgraduate supervisor/student relationship especially when there is a difference of ethnic culture and/or academic background between these two

\footnotetext{
${ }^{1}$ Assistant Professor, University of Asia \&
} the Pacific people. To some, it may appear ridiculous that there are even questions raised about the capacity of 'Asians' to think critically. Many scholars from Asian countries have developed this skill both at home and abroad while studying. Others will argue that 'critical analysis' is a Western concept that is inappropriate within the Asian context. This paper examines the outcome of a number of teaching and learning approaches as a way of opening up our thinking about this thorny issue. How might critical analysis be understood in a highly internationalised, yet locally accountable, university education system? In particular, what is the role of critical analysis in research and the production of new knowledge?

The basis for the discussion in this chapter is drawn from a diverse body of literature and from the research the author has conducted over the past 10 years. Some literature focuses on the development of the Western university from its earliest formation in Europe (see for example Ashby, 1967; Le Goff, 1993; Kerr, 1964; Newman, 1947); the literatures of the sociology of knowledge and the sociology of education have examined the production of knowledge, of which the work of the universities is seen as an intrinsic part (see Bordieu 1971a \& 1971b, 1988; Bordieu and Passeron, 1977; Clegg, 1979; Hicks, 1979; Hinkson, 1991; Illich and Verne, 1981; Lakshmana, 1976; Masseman, 1990; Opper et al., 1990; Scheler, 1921, 1924, 1960; Siedel, 1991). As the Western university system spread throughout the colonised world, and have been subsequently repositioned within a globalised post-colonial world, scholars 
increasingly turned to the examination of the role played by universities in our world (see, for example, Altbach, 1985, Altbach and Kelly, 1978; Althusser, 1972; Amornvivat, 1993; Apter, 1987; Beare and Slaughter, 1993; Bhabha, 1994; Hannerz, 1990; Harris and Jarrett, 1990; Ketudat, 1973; Nimmanhiminda, 1970; Ternai \& Ternai, 1995).

Research was conducted in both Australia and the Kingdom of Thailand about panjaa wisdom, khwaamruu knowledge and the transfer of academic knowledge across cultural differences between 1994 - 1997, initially forming the basis for higher degree work (Ma Rhea 1995, 1996, 1998). The author spoke to a diverse group of Thai academics, university administrators, government employees, and religious in developing the ideas for this chapter. Some of the informants are based in Bangkok and others are from Wat Suan Mokkh, Chaiya, or from the regional universities of Chiang Mai, Khon Kaen, and Haat Yai. Some work in publicly funded universities and teachers colleges while others work in private universities. the academics are located in the disciplines of education, linguistics, medicine, philosophy, economics nursing, and teacher education. All spoke of the role, function and applicability of Western knowledge within the Thai context, and critical analysis was a common point of discussion.

In continuing to work with postgraduate students and academics studying and working at Australian universities, the scope of the research has broadened to examine how knowledge is understood across cultural differences and to encompass the complexities of knowledge exchange in an increasingly globalised world (Ma Rhea 2000, forthcoming). The author recently also taught a Masters-level course in Thailand on 'Leadership and Communication' and sought to contextualise the materials within a bicultural classroom, exploring the relevance of the materials for the Thai context. the skill of critical analysis was pivotal to the students successfully completing the course. ${ }^{2}$

\section{Critical Analysis in Context}

At the outset, it is important to recognise that there is no biologically determined basis for claims about the differential abilities of a particular ethnic cultural group to 'critically analyse'. In such a discussion, we a clearly in the zone of socialisation and education in unravelling this issue. This paper will examine three approaches to the teaching and learning of critical analysis, particularly in relation to their success in achieving the desired 'outcome'. The consequences of each approach will be analysed in terms of its underlying pedagogic assumptions and local/global applicability. 'Critical analysis', not unlike 'speaking and understanding English', has become a desirable skill for many individuals, universities and governments through the persuasive influence of Western-led globalisation.In this way, discussions

\footnotetext{
${ }^{2}$ Sponsored by AUSAID and IDP Education Australia, and delivered in a collaborative partnership between Continuing Education Centre, Asian Institute of Technology, Bangkok Thailand and Swinburne University of Technology, Melbourne, Australia.
} 
about its acquisition, its manifestations and an individual's capacity to 'do it' have been put under the spotlight. The ability to 'critically analyse' has become loaded as a new marker of ability to succeed in one's university studies, particularly at the postgraduate level, to undertake research, and to earn the right to create new knowledge. A logical consequence of such a positioning is that some will be seen to have 'it' and some will not. It has become a marker that enables the differential distribution of privileges in a competitive university environment and an increasingly globally interdependent world where the right to produce and control new knowledge is a central factor (see various arguments by Althusser \& Balibar, 1970; Apter, 1987; Bruntland Report, 1988; Cerych, 1965; Dore, 1976; Fanon, 1986; Jacobs, 1971).

The fact that critical analysis has become an important marker of success in both the university and the modern world suggest that the question of the capacity of 'Asians' to do it, is in itself a fraught and often racist terrain of enquiry. Universities remain the predominant place where this set of skill is learnt and applied, so it is to the approaches to the teaching and learning of critical analysis within universities, particularly at postgraduate level, that this paper will now turn.

The diagram below (Diagram 1) indicates three levels of perspective that are necessary to consider when thinking about 'critical analysis' and its development in universities. The first level enables a discussion about international and national pressures and the 'bigger reasons' for the development of skill of critical analysis by students. The second level of analysis comprises pedagogical considerations. What impact does the teaching approach have on the development of this skill? The third level focuses on the internal awareness aspects of both teacher and learner in the development of critical analysis and the implications of having this skill set with in one'slife.

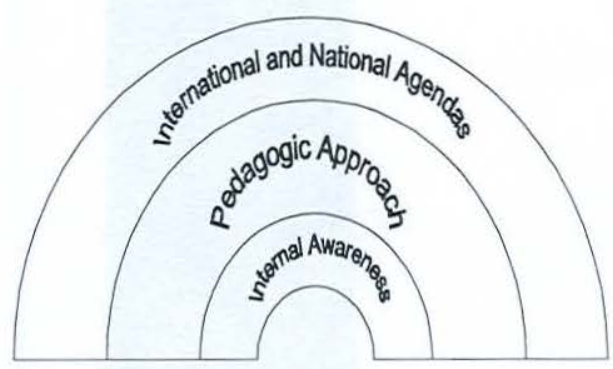

Diagram 1: Levels of Perspective

In this paper, I will primarily be focussing on the pedagogical level with reference to the other two as relevant. Forthe purposes of this discussion, I will first examine what is known as the 'Apprenticeship Approach' and will secondly look at the 'Culture-Relative Approach'. The third, or what I have called the 'Middle Way Approach', offers some ideas for negotiating the primary question posed by the paper, 'Can Asians critically analyse?' 
Central to all these approaches is the supervisor-student relationship. This paper will argue that this relationship is the primary site for the cultivation of the skill of critical analysis and it is this relationship that we need to examine, if we are to understand the complexities involved in acquiring the critical analysis skill set. However, there is little or no agreement on the location of a skill such as 'critical analysis' within the bigger picture of postgraduate work and therefore, the student-supervisor relationship needs first to be located within the broad approaches discussed below.

\section{The Apprenticeship Approach}

Diagram 2 below represents the teaching and learning approach adopted through an Apprenticeship Approach. While local cultural differences without doubt influence the way that universities work, there are also ways of doing things within universities that cut across local ethnic cultural expectations. There seems to be a symbiotic relationship between universities and national cultures, embodied in the supervisor of a postgraduate student. One of the central tenets of the modern university, regardless of national location, is the presumption that the Apprenticeship Approach prepares students; particularly higher degree students (Masters and $\mathrm{PhD}$ Level) to undertake research and create new knowledge. In this diagram, the large outer circle represents the supervisor.

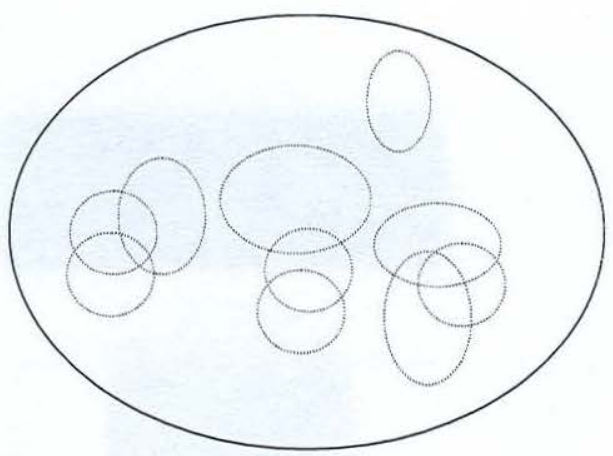

Diagram 2: The Apprenticeship Approach

Every prospective postgraduate student (the dotted-lined circles) is expected to learn how to fit into their university and department, via the relationship with the supervisor. Ideally, the supervisor is the expert in their subject and discipline and it is within the process of undertaking the postgraduate program that the student learns the skill of critical analysis. The supervisor role is, as has been found in earlier research, a pivotal role in the formation of these skill but such skill are also mediated through local expectations of what role critical analysis plays. The research found, for example, that Thai academics are constantly mediating Western knowledge through Thai cultural filters, as is their responsibility, and undertaking a process of what has been labelled 'adaptive balancing' in terms of evaluating the appropriateness of khwaamruuthangdaankanphadthanaa outsider knowledge for the local context (Ma Rhea, 1998, 2000).

Australian academics, as another example, have historically prepared postgraduate students for operating in a Western, or Westernised, context and have not normally undertaken to medi- 
ate critical analysis skill development to different cultural contexts within which the student might eventually work and apply their knowledge. In an increasingly internationalised university system where many postgraduate students are now undertaking studies outside their own country of residence, questions have been raised about how supervisors should develop skill such as critical analysis in their students, and also how necessary and appropriate these skill are for all students (Baba \& Nabobo, 1996; Barna, 1983: Kitchener and Brenner, 1990; Knowles, 1980; Lee and Ninnes, 1995). Dale (1982) provocatively titled his book 'Learning to be What?'

Before discussing the role of the supervisor, it is also important to consider what postgraduate students themselves are seeking when they study at postgraduate level. In discussions with Thai scholars studying at Australian universities, for example, there are two levels of understanding that need to be considered about Thai international scholars. At a personal level, many commented that study abroad has given them the opportunity to increase their status, improve their job prospects and that they will be able to command a higher salary on their return home because of their overseas studies. Thai university education, particularly postgraduate studies, is not considered as good as an overseas qualification. Nearly all said that they felt an enormous sense of responsibility to do well no matter whether they are being publicly or privately financed. One student said:

...when I heard the

news I was so

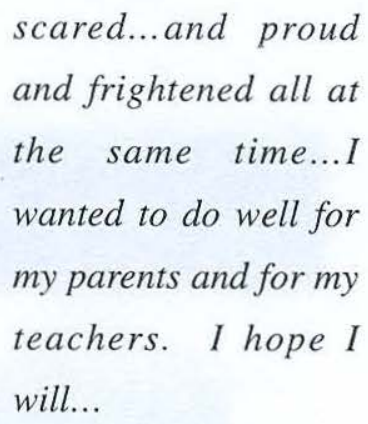

A common way of speaking about their experience as a student was how the study was always overshadowed by the importance of doing well for their parents. Also common was a reaction of culture shock. There is little research on this aspect of Thai students' experiences but some insight can be gained from the following:

$$
\begin{aligned}
& \text { Everything went } \\
& \text { wrong when I started } \\
& \text { my Australian } \\
& \text { university...because } \\
& \text { of myself who at the } \\
& \text { beginning was very } \\
& \text { shy, very close-self, } \\
& \text { especially very em- } \\
& \text { barrassed with my } \\
& \text { English and my for- } \\
& \text { eign accent. }
\end{aligned}
$$

A second way of understanding their study experiences was to look at feelings about responsibility to Thailand and was of evident importance when discussions were had with students who received AusAID or Royal Thai Government scholarships and who expected to return to Thailand to take up university 
or government employment. These students said they were always assessing the applicability of what they are learning in view of their future work responsibilities. Many commented that developing skill of critical analysis, while personally useful, would not necessarily be immediately useful to them on their return home.

In talking with these students, as in earlier research with Australian academics (Ma Rhea, 1992), the author found that the Australian approach to international students follows the Apprenticeship Approach as the following comments suggest:

$$
\begin{aligned}
& \text { Overseas students } \\
& \text { come here because of } \\
& \text { what an Australian } \\
& \text { system has to offer. } \\
& \text { Why change it? } \\
& \text { Eventually they do } \\
& \text { learn to adapt } \\
& \text { Once their English is } \\
& \text { better they fit in fine } \\
& \text { Bridging courses will } \\
& \text { bring them up to } \\
& \text { scratch }
\end{aligned}
$$

Some individual academics recognised that university knowledge needs to be relevant to the context of its application and a number commented on how hard it appeared to be for international students to learn the skill of critical analysis.

The third aspect that students spoke about reflected the changes that are occurring in Thailand due to the sustained economic development of the country and Thailand's greater participation in world affairs. For the individual Thai student, there had been increased scope for studying abroad because Thai families have become wealthier. This fact coupled with the growing existence of a very competitive international education product, meant that there are new opportunities for individual Thai scholars who enter the marketplace as consumers rather than as recipients of government scholarships.

Clearly, Thai people are responding to new global possibilities of purchasing an overseas education. This is occurring in parallel with the older practices of students going out into the world and bringing back khwaamruu knowledge for Thai national development. As was seen in my earlier research, many of the scholars are using education as a way of improving their activities in the sphere of private enterprise. Boulding (1966) predicted this growth of knowledge as a commodity and it is as yet unclear what the impact of this commodification will have on the development of skills such as critical analysis. Will it have an appeal in the new markets or not?

There have been notable successes in using educational co-operation for developing the bilateral relationship between Australia and Thailand (see, for example, Pookpakdi et al, 1988) but little is yet written on the impact of new ways of thinking that have become part of the experience of a postgraduate student who studies outside their own place of eventual residence.

The reality for Thai students studying outside Thailand is that they report hav- 
ing to overcome a formidable range of problems before they can begin to value the educational aspect of the exchange and that ultimately it is up to them as individuals to make what they can of the experience (Burke, 1990; Corbitt et al, 1995; Hannerz, 1990; Kongkoy, 1996). The opportunities presented to them particularly at postgraduate level do not yet make easy the actual meeting of expectations between the student and their supervisor, and the differing expectations within the internationalised university system. The opportunities make it more possible to meet these expectations but it is still up to individual students and supervisors whether those cross-cultural events culminate in a 'successful' education experience where the development of skill such as critical analysis are embedded within the experience.

Individual responses to global possibilities are influenced by the responses also being made by people in universities and those making government policies. University students from Thailand spoke about it being very important to know about the world in which they lived. It was clear that Thailand has had a longer experience than most countries of scholars going outside Thailand to gain and bring back many different sorts of outsider knowledge. Kings Mongkut and Chulalongkorn began the process of engagement with other countries through education exchange, but this was done under the pressures of colonisation, the precursor to the current impact of global market forces and a nationally driven need for scholars to have the skill of critical analysis.

The practice of going all over the world to get an university education is a rela- tively new global phenomenon outside the elites of most countries and the larger picture of international student migration under global market forces has not yet been recognised as being of significant research interest. Global capital requires a mobile elite workforce that is comfortable with working in a variety of national contexts. The university is being brought in to train people for this mobility. International student mobility is becoming an important part of the processes of market globalisation, and ability to think critically is seen as an important 'success' marker.

Thai policy makers continue to foster Thailand as a regional hub for education in the technologies needed for development, while ensuring that their university graduates continue to have the necessary khwaamruu knowledge to protect Thailand's interests in the region. Thai academics have not yet developed a strong locally controlled research capacity and Thai universities are not placed highly in the global hierarchy of vichaa university knowledge production and reproduction. Similarly, Australian academics are dependent on the global research agenda being set by countries such as the United States, Germany, Japan, and the United Kingdom. Australia is better placed globally to attract overseas students, and be involved in the reproduction of khwaamruusamaymai new knowledges for reasons examined elsewhere (Ma Rhea 1996).

There was evidence in Thai universities of an awareness of the need to produce as well as to consume the knowledge commodity. Academics and government respondents both said they recognised a 
need for the preservation of Thai cultural identity in the new global world and to create their own vichaa university knowledge they needed the capacity for independent research. Hence, the need for Thai people to think critically and analyse the volumes of information now available has become linked to the independent production of new khwaamruu knowledge through research.

In Bourdieu and Passeron's (1977) terms both Thai and Australian university systems have received 'new' university knowledge, exchanged it, and reproduced it in the local context. Both nation states are eager to have collaborative research with more powerful nations because, as both Thai and Australian bureaucrats and politicians are aware, to lose access to advanced knowledge production and reproduction threatens the ability of each nation to function in the globalised economy, and might render the nation vulnerable as an organising structure.

In Althusser's (1971) terms, Thai and Australian universities are reproducing the existing relations of production within the global market. Kristeva (1977, p. 294-5) predicts a separation between the people who can think, the intellectuals, and the machinery of knowledge reproduction that no longer searches for new knowledge but satisfies a global consumer market. She further suggests that the intellectual is, because of their new global mobility, exiled from the Althusserian ideological state apparatuses and dissident to the reproductionof-technology project (p. 298). Kristeva's predictions are echoed in the discussions that the author had with some Thai and Australian academics who are trying to teach in a university system that is radically changing. The intrusion of market forces had left them feeling disillusioned with their future role in the university. Others are content with the changes that are occurring, seeing the university's new responsiveness to the market as a positive thing for them.

There is pressure from Thai and Australian politicians and bureaucrats for academics to internationalise their course content but little direction is given on how this might be achieved. Academic respondents expressed uncertainty about how to improve competency and competitiveness of students in a globalised world, the demands of which were not yet clearly understood, and ask serious questions about the role of the university in their countries (see for example Amornvivat, 1993, who analyses the Thai international education relationship with Japan; Beasley, 1991, who discusses Australian university attempts at internationalisation; Berchem, 1991, who examines German responses to internationalisation; Hayhoe, 1996, looks at the international role of Japanese universities; Kobayashi, 1986, examines the Japanese response to internationalisation; Kim, 1996, researches the role of the university in Malaysia; Laureys, 1992, who argues that mobility is a necessary aspect of newly internationalised universities; Pongpisit, 1994, who examines a Thai university's response to internationalisation; and Seidel, 1991, looks at the overall challenge of internationalisation to the university ideal). Some Thai respondents suggested that ideas about globalisation, and such skill as critical analysis, are sim- 
ply disguised justifications for a process of Westernisation, imposing Western economic models, technological information, and ways of thinking on countries such as Thailand (see also a thoughtful discussion by Tapingkae, 1985). Australian academics have also questioned the value of exporting knowledge for both its cultural and educational implications (Alexander \& Rizvi, 1993; FitzGerald, 1993; MacKinnon, 1995).

The capacity and ability to "critically analyse' in both Australia and Thailand operates today in a policy-making environment that is internationally interdependent. Each nation wants to be modern and economically developed without losing a sense of local cultural identity (in the case of Thailand, see Jacobs, 1971).

In Thailand, the university in the past performed a special function for the emerging modern state of Thailand in providing training for the bureaucrats who would facilitate this emergence. There was a mixture of state-funded, free to the student universities and an increasing number of privately financed universities. Thai universities, since their establishment, were outward looking, sending their students to many different universities around the world to gain access to vichaa university knowledge particularly at the higher degree level. In the stage where Thailand was developing as a modern state, there was collaboration with more developed nations to improve the Thai university system (Ketudat, 1973).

The commodification of university knowledge by such nations as Austra- lia, concurrent with the rapid economic development in Thailand that has heralded a growth in the middle class and their demands for university education, has influenced old global awareness. The commodification of university knowledge has broken the nexus between high social status and access to university knowledge because the newly rich families in Thailand are not necessarily of the groups that were the elites (Hayden, 1967).

The implications of this discussion for pedagogical approaches are crucial to understand. The ability to think critically is, as was suggested earlier, a loaded issue. This skill has become a marker of success within the internationalised university system, and is also seen as important skill for a country such as Thailand to have, to ensure that Thailand maintains the capacity to produce new ways of doing things that cushion Thailand from the impact of globalisation.

There is a growing body of research on the student-supervisor relationship within the universities of any one country. Australian research has contributed to our understanding of this aspect of learning (see for example James and Baldwin, 1999). The research has predominantly been done under an assumption of the 'universal' aspects of postgraduate work and the supervisor-student relationship. The underlying assumption, therefore, has been that the student can assimilate into the supervisor's expectations, becoming the apprentice.

While this approach avoids the potentially more difficult 'culture-relevant' aspects where the supervisor and stu- 
dent do not share the same ethnic cultural or academic background, there is significant anecdotal evidence that suggests there are problems associated with the 'universalist' approach because of the impact of cultural differences.

In summary, under the Apprenticeship Approach, the development of the skill associated with critical analysis is cultivated within the supervisor-student relationship. It is therefore important to discover the 'fit' between a supervisor and a postgraduate student such that the supervisor can transfer this skill and the student can learn them within the relationship. While the universalist, apprentice approach has been the modus operandi within many universities around the world as the way of fostering the skill of critical analysis, this approach has been questioned now that supervisors and students are increasingly likely not to share a common ethnic culture or academic background in our internationalised university system. It has also been questioned by academics in nonWesternised countries that see the acquisition of such skill as critical analysis as being counterproductive to the maintenance of local identity.

\section{The Culture - Relevant Approach}

This approach, depicted in Diagram 3 below, questions the universal applicability of a skill set such as critical analysis. Each circle represents a national university culture such as Thailand, Australia, USA or Japan and suggests that the university mission should be more aligned to the local culture than the demands of the global culture.
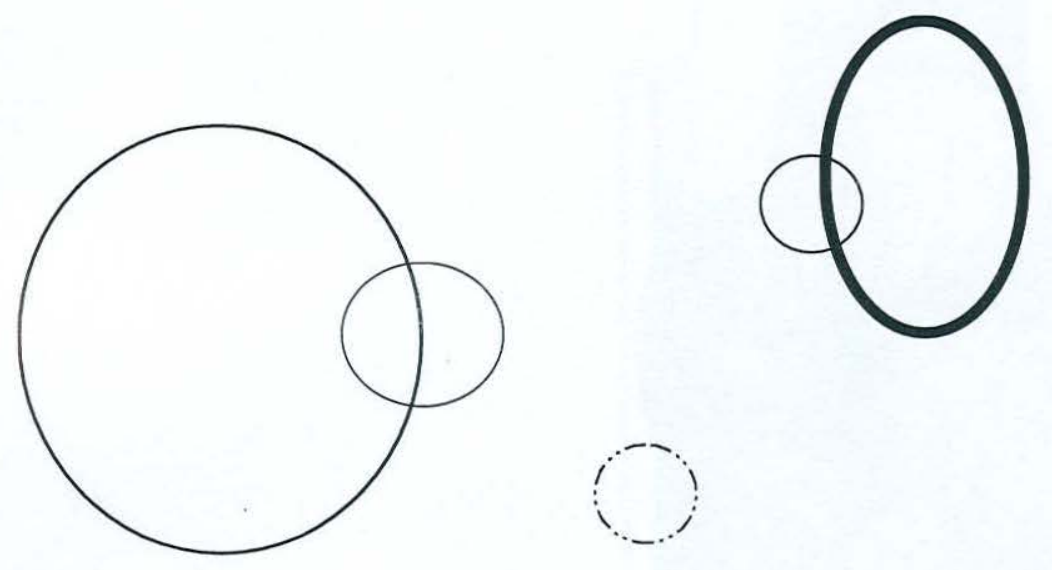

Diagram 3: The Culture-Relevant Approach 
The basic tenet of this approach is that local and indigenous knowledge and local forms of education and socialisation take precedence over globally derived knowledge and pedagogical approaches. This approach has emerged in many ways a s a response to the homogenising influence of Western knowledge under colonisation and newer forms of globalisation (see Baba, 1987; Bar On, 1993; Bhabha, 1994; Boonyavatana, 1995; Corbitt, et al., 1995; Fanon, 1986; Geertz, 1983; Teasdale and Ma Rhea, 2000). It reasserts the right of local communities to preserve their particular worldview in the face of outsider views and suggests, as an example, that critical analysis is one such outsider view within many cultures (Nabobo, 1994; Thaman, 1995; Said, 1978, 1994 a\&b). Hofstede \& Harris (1988) suggest that different cultures will drive capitalism and organisational development differently because of the cultural factors and that Western indicators of success are not necessarily useful to non-Western, economically developing nations.

There have been a number of responses at the pedagogical level to this assertion. Some academics appeal to the Apprenticeship Approach, that all students regardless of ethnic, national culture will benefit from developing the skill of critical analysis (see for example Honey's argument in parallel about the learning of English language, 1998; Sethasathien, 1995; Thanasuthipitak, \& Ramingwong, 1995). In this response, as was discussed above, critical analysis is posited as a universal 'good'. For other academics, the teaching of critical analysis is so destructive of ethnic or national cultural identity that the skill of critical analysis is framed as 'Western' and is described as belonging to 'Western' culture.

These responses will be discussed drawing from research that has focussed on learning styles. The Culture-Relevant approach, sometimes also called 'culture-relative' has a surprising array of proponents coming from different ethnic cultural locations but arguing similar points. The arguments have been generated by the increasing possibility that supervisor and student do not share a similar ethnic culture or academic background. As was discussed above, there seems to be evidence that the development of skill such as critical analysis is fostered by a good 'fit' between the teacher and the learner. For some teachers and learners, the presence of ethnic cultural differences between them makes this an uncomfortable 'fit'.

Comments, drawn from my research, suggest the approach of some Australian academics:

The Chinese learning style is so fundamentally different from ours that I need to supervise to accommodate these differences

I can't expect Asian students to critically analyse things because it is not part of their culture to do so

They mostly need to learn things that will be useful to them back home and not 
MANUSYA:Journal of Humanities(Special Issue.No.1-2.2001)

\section{learn Western ways of doing things}

Typically, this argument is more commonly made by academics who are working with large numbers of students who do not share their ethnic cultural or academic background. In conversations and at workshops they speak of the difficulties of developing the sort of relationship with their students that they feel one needs in order for the student to develop the skill of critical analysis. They point to the foundational factors such as getting to know the student and assessing their needs, or establishing reasonable, agreed expectations, or encouraging the postgraduate student to be an independent thinker as areas of great problem for many overseas students. In failing to find the appropriate 'fit' presumed in the Apprentice Approach, many academics focus on cultural differences as a source of the problem.

There are many universities in Australia that now offer academics the opportunity to develop cross-cultural skill, both at the interpersonal and the pedagogic levels. The positive aspect of this professional development is that academics are questioning the appropriateness of the Apprenticeship Approach as universally applicable. It also raises problems. The Apprenticeship Approach is predicated on the supervisor being the expert and the student being the learner. From experiences of running this sort of staff development workshop, the author has become aware that many academics, who have worked long and hard to become expert in their field, find it very difficult to become a learner again, particularly when they are clearly non-expert about the student's ethnic culture and possibly are unfamiliar with their academic background as well.

They often want easy solutions and clear answers about the impact of cultural difference and learning styles on the supervisor-student relationship. Sometimes the discussions become uncomfortably essentialist because of the need for academics to have the answers. Examples of the extreme are found in the above comments. It is here that the author most often hears the question about whether people from a particular cultural group can 'critically analyse'. The logic of the approach is that ethnic culture has an impact on learning style. When the learning style of the student is different to that of the supervisor, is it necessary for the supervisor to adjust their approach to meet the expectations of the student? If critical analysis is not part of the student's cultural background then does it make it far more difficult, if not impossible, for the student to develop such a skill?

While under the Apprenticeship Approach the student is expected to do most of the adjusting and fitting in, under this approach it is the supervisor who predominantly undertakes this task. By necessity, the supervisor can fall into an eclectic reading of their role falling somewhere between a demi-god whose words the student uncritically accepts, and a learner who elevates the student to the 'native expert' position.

However, it is not only Westernised academics who favour the Culture-Relevant Approach. There are a number of nonWesternised academics who question the value of critical analysis as a "uni- 
versal' good. While outside the scope of this paper, there has been robust criticism of the claims to universality enshrined in the mission of most universities that were established during the recent period of European colonisation. In the post-colonial period, many universities in countries such as India, the Caribbean, Malaysia, and South Africa were invited to reform themselves such that they could make a significant contribution to the development of postcolonial states. The reconfigured universities were often part of the newly emerging national identity. There have been many discussions, conferences and papers about the role of universities in developing areas and the skill of critical analysis have often been framed as part of a Western paradigm, and not suitable for the emerging state (see the conference proceedings of an organisation such as INRUDA: The Role of Universities in Developing Areas; Ma Rhea, forthcoming; Samuel, 1996).

As such, it is not surprising that academics in many non-Western locations have valued the rebuilding of national identity over the criticism of it. Students from countries that are emerging from a colonial past often have contradictory feelings about being critical of anything to do with their home country and culture, and it is especially difficult for an 'outsider' academic to encourage such students to develop these skill, even in the abstract (Rizvi, 1996; Simkin, \& Boonyanate, 1996; Sinlarat, 1994).

Very little research has focussed on the validity of either the Apprenticeship or the Culture-Relevant Approaches in terms of the development of, and appro- priateness of, the skill of critical analysis. What is known, however, is that in a globalised world, with the increase in international student migration, it has become far more likely that supervisors and their postgraduate students will not share a common academic background and/or ethnic culture. It is also clear that the relationship between the supervisor and student is an important influence on the success or failure of a student to acquire the skill of critical analysis. It is to the next approach that we now turn to examine how the gap between the former two models might be traversed.

\section{The Middle Way Approach}

Clearly, the discussion about whether 'Asians' can or should develop the skill of critical analysis is highly contested. Is it possible to move forward in such a way as to meet the concerns of both the universalists and the relativists? Is it possible to achieve the balance of competing needs as shown in Diagram 4 below, to develop a way forward that enables us to think about the development of the skill of critical analysis without falling into dangerous cultural determinism or new forms of colonisation? 


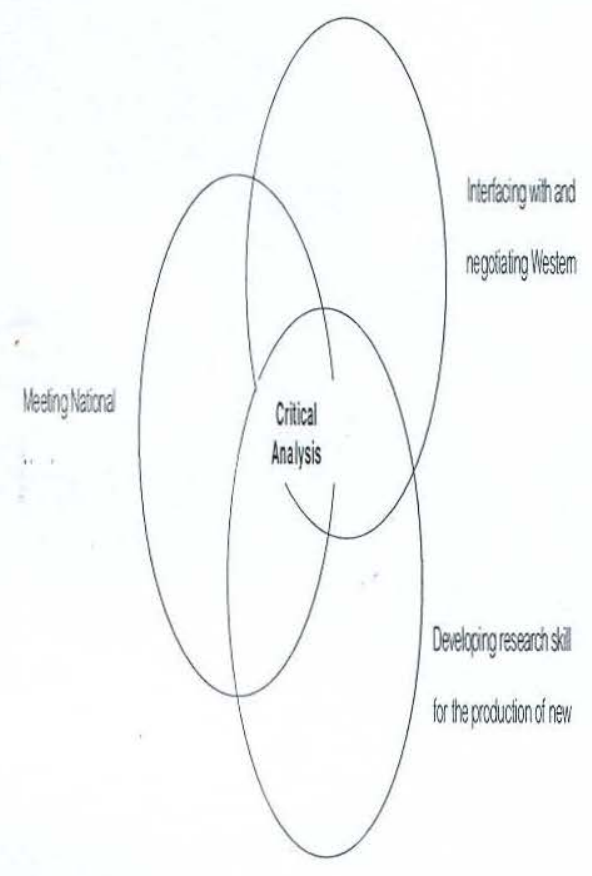

As was seen from Diagram 1, there are complex international, national, pedagogical and individual perspectives on the acquisition of the skill of critical analysis. When the two people most central to this task, the supervisor and the student, are working together they are consciously or unconsciously shaped by these perspectives. This section of the paper will argue that there is a need for there to be a higher order motivator that might encompass both the universal and particular aspects that shape the teaching and learning of critical analysis. In earlier work (Teasdale and Ma Rhea, 2000), the author has argued that panjaa wisdom might be such a motivator. This approach is supported by a growing body of literature that suggests that pursuit of panjaa wisdom is an important goal towards which to focus the development of khwaamruu knowledge (Ayya Khema, various; Bauman, 1993; Beare \& Slaughter, 1993; Buddhadasa Bhikku, various; Conze, 1980; Fals Borda, 1985; Nabobo, 1994; Shweder, 1991; Sternberg, 1990).

The pursuit of panjaa wisdom also suggests that bodies of knowledge such as Buddhism still have within them a pedagogical contribution to make to our understanding of critical analysis. It can also point the way forward to our questions about how to ensure that the skill that we are teaching in our universities are culturally safe and sensitive for all our students regardless of their ethnic culture. The diagram following (Diagram 5) provides a useful explanation of the interrelationship of various forms of knowledge and panjaa wisdom.

Vipassana insight understanding and the skill of critical analysis seem very similar. If these ways of analysis can be harnessed to local expressions of moral/ ethical principle then we would have two legs of the pot. The third, concentration arising from meditation and stillness of mind, seems the weakest in the present climate of change. Both Harvey (1989) and Giddens (1992) write of the sense of time speeding up, of humans now having to work more rather than less even with our technological mastery. Every time that I suggested to my research participants that it might be a good idea to slow things down in the global education services market and to think about what we are doing, there was strong objection, with one informant saying, "If we don't do it, somebody else will".

I think that the capacity to refuse plan- 
Approach to the Development of Critical Analysis in the University:

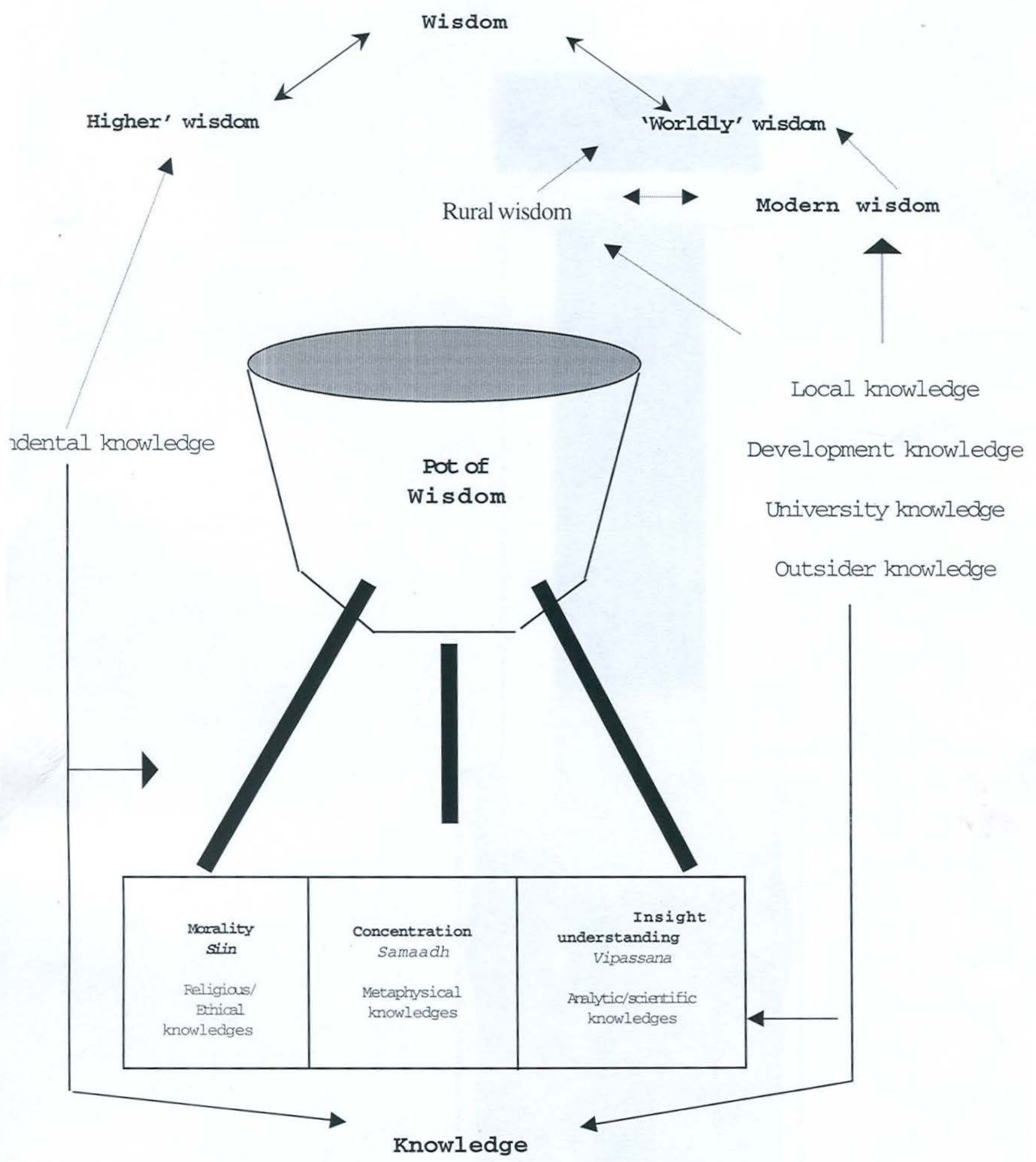

Diagram 5: The Three- Legged Pot 
etary destruction lies in the skill that arises from such forms of concentration samaadhi as meditation. The word 'meditation' is often misunderstood, with most people being content to seek moral/ ethical transcendental knowledge rather than to pursue deep concentration. Many mind-stilling techniques are available (see for example Ayya Khema, 1987, 1991; Buddhadasa, 1956, 1986, 1988, 1989; Buddhaghosa, ?400; Inthankamhaeng, 2536; Nyanatiloka, 1981, 1982;) but all these techniques are simply methods to occupy the caj mind (brain and the heart) so that brief moments of stillness can be experienced. It is in this space of stillness and insight understanding that new knowledge can arise.

What is implied by this three-legged pot analogy is that if we simply strengthen the critical analysis skill without attending to ethics and the ability to concentrate, then the outcome will not be a wise one. It would seem that this information provides a useful insight into the dilemmas faced by supervisors, their students, universities, individuals, and governments. Surely we need new knowledge that is wise, not new knowledge that is solely well analysed. That is part of the skill needed to conduct appropriate research and produce new knowledge. This Middle Way Approach attempts to position panjaa wisdom as its universal good, enabling discussion of both critical analysis and its role in the world in relation to wise outcomes.

The relationship of wisdom to the Western scientific tradition, of which critical analysis is an important part, is one of the most complicated ones to understand. It was striking how frequently Thai in- formants pointed to Western science as a form of panjaa wisdom, whereas Australia informants had been saying that scientific knowledge without ethics was something potentially dangerous. After reviewing the research data, a theme emerged that indicated that khwaamruu knowledge and panjaa wisdom are not necessarily of the same order even though many informants used the terms interchangeably. The words are also often confused in the academic literature. In returning to Theravadan Buddhist orthodox understanding of panjaa wisdom and khwaamruu knowledge, it was apparent that there are similar levels of confusion in the interpretative texts. Buddhist texts now teach the three ways of knowing as morality, concentration and wisdom in the teachings (siinsamaathipanjaa) about ariya-sacca the Four Noble Truths and ariya-atthangika-magga the Noble Eightfold Path (see Diagram 6; Bhikku Bodhi, 1984). Thus, panjaa wisdom has tended to be seen as a sequential development after siin morality/ethics, and samaathi concentration. In fact, the first two need also to be supported by vipassana insight understanding, working together before panjaa wisdom can arise. Moreover, it is vipassana insight understanding that can also be understood as critical analysis. 


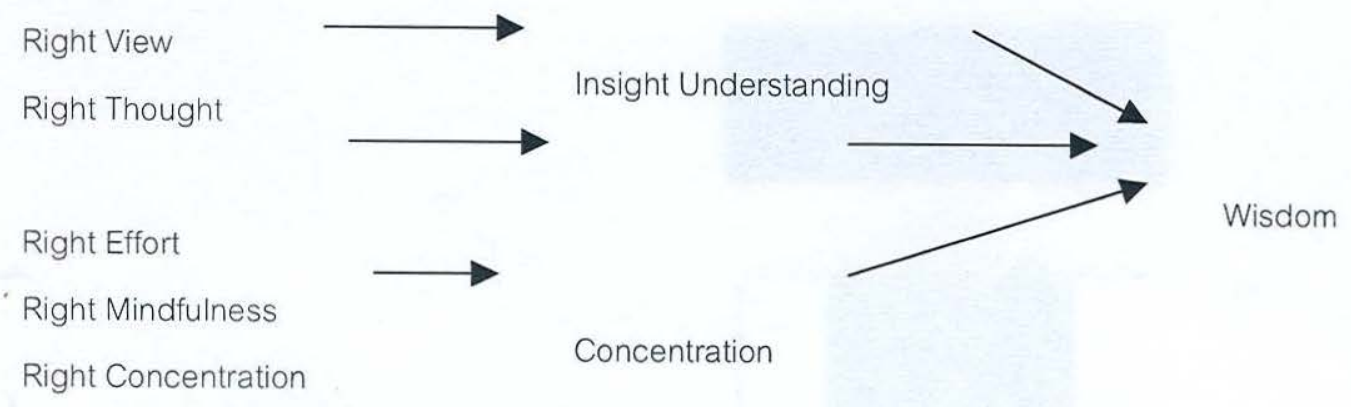

Diagram 6: Revisiting the Relationship between Wisdom and Knowledge

When reanalysing the actual practices that were being called panjaa wisdom, they were insight understanding practices that in conjunction with morality and concentration could lead to an experience of panjaa wisdom. The informants who insisted that panjaa wisdom is higher than knowledge provided the key to unravelling the mess. Equally, Thai informants insistence that science could be regarded as a form of panjaa wisdom then became clearer, because Thai Buddhist are taught that panjaa wisdom is the insight path. It then became clearer that what these Thai informants were saying was that the Western scientific way of knowing about the world was very similar to the way of knowing that encourages insight understanding. Both are practices of deep understanding if applied correctly.

The revised proposition about ariyaatthangika-magga the Noble Eightfold Path now suggests that panjaa wisdom, whether 'higher' wisdom or 'worldly' wisdom, is the outcome of practice and understanding of the three ways of knowing.In such a way, the pot of panjaa wisdom is constantly replenished and balanced.

The scientific way of knowing was also an important part of discussion with Thai academics and students. The established Thai practice of bringing Western science into a clear Thai cultural framework tried to make sure that this new $k h w a$ a mru $t h$ a angda an kanphadthanaa outsider knowledge, vichaa university knowledge was balanced with local knowledge and, sometimes, phumpanjaachawbaan rural wisdom.It remains to be seen whether the increases in funding for the migration of Thai scholars to overseas universities to gain access to new vichaa university knowledge in science, engineering, informatics and computer technologies will disrupt the adaptive balancing that has occurred up until now. It will be influenced by the scholars themselves, by how they bring the newer vichaa university knowledge back to Thailand, by how they filter what they have learned, and by how they act because of their global awareness and their global knowledge. 
What becomes clear is that global university knowledge is being brought into nations such as Thailand by returning students and that such outsider development knowledge poses a serious challenge to phumpanjaachawbaan rural wisdom. I found that this sort of panjaa wisdom had been built on the past, on past experiences and on cultural storehouses of local knowledge. As such, there was a reliance on the relative stability of Thai society on which to base wise pronouncements, so it could therefore be seen to be inherently conservative.

Vichaa university knowledge is seen as a tool by which to construct a different, better future. Phumpanjaachawbaan rural wisdom withers before vichaa university knowledge because university knowledge accommodates change. University graduates know that their university knowledge becomes outdated by new discoveries. They are trained to be open to such a process, and to be questioning of ways of knowing that look for solutions to problems outside the material.

Training in the traditional Buddhist siinsamaathipanjaa wisdom path insists that there is more to insight than the physical manifestations of materiality. Transcendental understanding would incorporate change while teaching that solutions to material problems can be found in balancing the three ways of knowing.

\section{Conclusion}

The above sections prepare the ground for an understanding of the Middle Way
Approach. Returning to the subject of this paper, there are clear, scholarly indications that the Western way of critical analysis is similar to the Buddhist insight understanding. What is interesting is that Western universities have chosen to focus on, and develop critical analysis within the scientific paradigm and have not maintained its pedagogic relationship with ethics and concentration. What is also interesting is that many of the Thai people spoke of the fact that Thai people generally are well grounded in the ethical, moral knowledges (siin), fewer learn the mind stilling practices of concentration through meditation (samaathi) and even fewer learn the skill of insight understanding vipassana.

Clearly there are historical reasons for the choices that ethnic cultural groups have made in their pursuit of khwaamruu knowledge and panjaa wisdom. What this paper attempts to show is that the skill of critical analysis is not unique to the West, but in the example of Thailand, it is not something that is commonly pursued. Within the pedagogy of Buddhism, it is clear that there are certain practices that can strengthen the development of vipassana just as there are within the Western scientific tradition. What seems to be at odds here is that the acquisition of the skill of critical analysis in the Western university context is unmoored from ethical considerations, an aspect that many overseas students spoke of in interviews. Neither is the ability to think critically necessarily developed alongside the skill of deep concentration about the issue of research. It appears to depend on the individual supervisor as to how much a student is encouraged to 
Approach to the Development of Critical Analysis in the University:

think ethically, deeply and critically about their research.

\section{References}

Alexander, Don and Rizvi, Fazal. 1993. 'Education, Markets and the Contradictions of Asia-Australia Relations'. The Australian Universities' Review 36(2), Pp. 16-20.

Altbach, Philip G. 1985. An ASEANAmerican Dialogue: the Relevance of American Higher Education to Southeast Asia. Singapore, Regional Institute of Higher Education and Development.

Altbach, Philip G. and Kelly, Gail P. 1978. Education and Colonialism. New York, USA and London, UK: Longman.

Althusser, Louis. 1971. 'Ideology and Ideological State Apparatuses'. In Education: Structure and Society. Edited By B. R. Cosin. 1972. Hammondsworth, UK: Penguin, Pp. 242-80. and Balibar, Etienne. 1970. Reading Capital. Translated By Ben Brewster. New York, USA: Pantheon Books.

Amornvivat, Sumon. 1993. 'Internationálization in Education: The Bridge over Troubled Waters (JapaneseThai Case)'. Chulalongkorn Education Review 1(1), Pp.17-32.
Apter, David E. 1987. Rethinking Development: Modernisation, Dependency, and Post Modern Politics. Newbury Park, UK: Sage Publications.

Archer, Margaret. 1990. 'Resisting the Revival of Relativism'. In Globalization, Knowledge and Society. Edited By Martin Albrow and Elizabeth King. London, UK: Sage Publications, Pp. 19-33.

Asad, Talal. 1973. Anthropology and the Colonial Encounter. New York, USA: Humanities Press.

Ashby, Eric. 1967. 'The Future of the 19th Century University'. Minerva 6(1), Autumn, Pp. 317.

Ayya Khema Bhikkuni. 1987. Being Nobody, Going Nowhere: Meditations on the Buddhist Path. Boston, USA: Wisdom Publications.

1989a. All of Us. Sri Lanka: Sarvodaya Vishva Lekha. 1989b. Be an Island unto Yourself. Sri Lanka: Sarvodaya Vishva Lekha. .1989c. Here and Now. Sri Lanka: Sarvodaya Vishva Lekha.

. 1989d. Little Dust in Our Eyes. Sri Lanka: Sarvodaya Vishva Lekha. 1991. When the Iron Eagle Flies: Buddhism for the West. London, UK: Arkana. 
Baba, Tupeni. 1987. 'Academic Bucaneering Australian Style: the Role of Australian Academics in the South Seas'. Journal of Education Studies 9(1), Pp. 3-11. and Nabobo, Unaisi. 1996.

'Yalomatua in Higher Education: the Dilemma Between Individual and Collective Knowledge'. Paper given at the 9th World Conference of Comparative Education, University of Sydney, 1-6 July, 1996.

Bain, Margaret S. and Sayers, Barbara J. 1990. 'Degrees of Abstraction and CrossCultural Communication in Australia'. Paper Presented At the Sixth International Conference on Hunting and Gathering Societies. Fairbanks, Alaska. May 28 To June 1, 1990, Pp. 1-15.

Bar on, Bat-Ami. 1993. 'Marginality and Epistemic Privilege'. In Feminist Epistemologies. Edited By Linda Alcoff and Elizabeth Potter. New York, USA and London, UK: Routledge, Pp. 83-100.

Barna, L.M.. 1983. 'The Stress Factor in Intellectual Relations'. In Handbook of Intercultural Training Volume II. Édited By Dan Landis and Richard W. Brislin. New York, USA: Pergamon Press, Pp. 19-49.
Barrows, Howard S. and Tamblyn, Robyn M. 1980. Problem-Based Learning: An Approach to Medical Education. New York, USA: Springer Publishing Company.

Bauman, Zygmunt. 1987. Legislators and Interpreters: On Modernity, Post Modernity and Intellectuals. New York, USA: Cornell University Press.

1988. 'Sociology and PostModernity'. Sociological Review 36. 1990. 'Modernity and Ambivalence'. Theory, Culture and Society 7 , Pp. 143-69.

1993. Postmodern Ethics. Oxford, UK: Blackwell. 1995. Life in Fragments: Essays in Post-Modern Morality. Oxford, UK and Cambridge, Massachusetts, USA: Blackwell.

Beare, Hedley and Slaughter, Richard. 1993. Education for the Twenty-First Century. London, UK and New York, USA: Routledge.

Beasley, Vic 1991. 'Can Higher Education $\mathrm{Be}$ Internationalised?' Higher Education Research and Development, 10.

Berchem, Theodor. 1991. 'The Internationalisation of Higher Education: The German Perspective'. Higher Education 21(3), Pp. 279-304 
Bhabha, Homi K. 1994. The

Location of Culture.

London, UK: Routledge.

Bhaskar, Roy. 1986. Scientific

Realism and Human

Emancipation. London, UK:

Verso.

1989. Reclaiming Reality: A

Critical Introduction to

Contemporary Philosophy.

London, UK and New York,

USA: Verso.

Bhikkhu Bodhi. 1984. the Noble

Eightfold Path. Kandy, Sri

Lanka: Buddhist Publication

Society.

Blum, Alan F. 1971. 'The Corpus of

Knowledge as Normative

Order'. In Knowledge and

Control: New Directions for

a Sociology of Education.

Edited by Michael Young.

London, UK: Collier-

Macmillan, Pp. 117-32.

Boonyavatana, Panit. 1995. 'The

University: as a Human

Resource Center for the

Community'. Paper

Presented At the Fourth

International Symposium on

the Role of Universities in

Developing Areas,

Proceedings Volume 1,

Section 6D, 11 - 14 July, 1995 ,

Melbourne, RMIT.

Boulding, Kenneth E. 1966. 'The

Economics of Knowledge and

the Knowledge of

Economics'. In Economics

of Information and

Knowledge. Edited By

Donald M. Lamberton. 1971.
Hammondsworth, UK:

Penguin Books, Pp. 21-36.

Bourdieu, Pierre. 1971a. 'Intellectual

Field and Creative Project'.

In Knowledge and Control:

New Directions for A

Sociology of Education.

Edited By Michael Young.

London, UK: Collier-

Macmillan, Pp. 161-88.

1971b. 'Systems of

Education and Systems of

Thought'. In Knowledge and

Control: New Directions for

a Sociology of Education.

Edited by Michael Young.

London, UK: Collier-

Macmillan, Pp. 189-208.

1988. Homo Academicus.

Translated by Peter Collier.

Cambridge, UK: Polity Press.

1990. In Other Words: Essays

Towards a Reflexive

Sociology. Cambridge, UK:

Polity Press.

and Passeron, Jean-Claude.

1977. Reproduction in

Education, Society and

Culture. Translated by Richard

Nice. London, UK:

Sage Publications.

(Brundtland Report.) 1988. Our

Common Future. World

Commission on Environment

and Development. Oxford,

UK: Oxford University Press.

Buddhadasa Bhikku. 1956.

Handbook for Mankind.

Bangkok, Thailand: Sublime

Life Mission. 
: 1986. Dhammic Socialism.

Bangkok, Thailand: Thai Inter-

Religious Commission For

Development.

: 1988. Buddha-Dhammafor

Students. Bangkok, Thailand:

the Dhamma Study and

Practice Group.

: 1989. Key to Natural Truth.

Bangkok, Thailand: the

Dhamma Study and Practice

Group.

Buddhadatta Mahathera. 1979.

English-Pali Dictionary.

London, UK: Pali Text

Society.

Buddhaghosa. ?400.

Visshudimagga: Path of

Purification. Fifth Edition.

Translated by Bhikku

?anamoli. 1991. Kandy, Sri

Lanka: Buddhist Publication

Society.

Burke, B. 1990. 'Meeting the

Reasonable Expectations of

Overseas Students'. Paper

presented to the International

Education Seminar on

Overseas Students. 31 July,

1990. Adelaide, Australia.

Cerych, Ladislav. 1965. Problems of

Aid to Education in

Developing Countries. New

York, USA and London, UK:

Praeger.

Chuaprapaisilp, Arphorn. 1989. Improving Learning from

Experience through the

Conduct of Pre- and Post-

Clinical Conferences: Action

Research in Nursing
Education in Thailand.

Unpublished PhD Thesis, School of Medical Education, University of New South Wales, Sydney, Australia.

Clegg, Stewart. 1979. 'The Sociology of Power and the University Curriculum'. In Control and Knowledge: the Mediation of Power in Institutional and Educational Settings. Edited by M.E. Pusey and R.E. Young. Canberra, Australia: Australian National University Press.

Conze, Edward. 1980. The Way of Wisdom. Kandy, Sri Lanka: Buddhist Publication Society.

Corbitt, Brian, Mcburnie, Grant and Siribumrungsikha, Boonsom. 1995. 'Cultural Difference in Experience of Exchange Students Thailand/Australia: Providing the Props'. Paper Presented at the Fourth International Symposium on The Role of Universities in Developing Areas, Proceedings Volume 1, Section 4A, 11-14 July, 1995 , Melbourne, RMIT.

Creel, Herrlee G. 1960. Confucius and the Chinese Way. New York, USA: Harper.

Dale, Roger. 1982. 'Learning To Be What? Shaping Education in Developing Societies'. In Introduction to the Sociology of Developing Societies. Edited by Hamza Alavi and Teodor Shanin. London, UK: Macmillan. 
Dore, Ronald. 1976. The Diploma

Disease: Education, Qualification and Development. London, UK: Allen and Unwin.

Fals Borda, Orlando. 1985. 'A Rediscovery of Wisdom as Power'. Plenary Paper Presented At World Development: Risks and Opportunities 18th World Conference. Rome, Italy: Society for International Development.

1990. 'The Application of Participatory-Action Research in Latin America'. In Globalization, Knowledge and Society. Edited by Martin Albrow and Elizabeth King. London, UK: Sage Publications, Pp. 79-97.

Fanon, Franz. 1967. The Wretched of the Earth. Hammondsworth, UK: Penguin. 1986. Black Skin, White Masks. Translated by Charles Lam Markmann. London, UK: Pluto Press.

FitzGerald, Stephen. 1993. 'Ethical Dimensions of Australia's Engagement with Asian Countries: Are There Any?' Occasional Paper Number 1, Asia-Australia Institute, University of New South Wales, Pp. 1-12.

Foucault, Michel. 1991. The Archaeology of Knowledge. Second Reprint. London, UK: Routledge.
Gannon, Martin J. 1994.

Understanding Global

Cultures. California, USA:

Sage Publications.

Geertz, Clifford. 1983. Local

Knowledge. New York, USA: Basic Books Inc.

Hall, Edward T. 1959. the Silent Language. New York, USA: Premier Books.

1989. Beyond Culture. New York, USA: Anchor Books.

Hannerz, Ulf. 1990. 'Cosmopolitans and Locals in World Culture'. Theory, Culture and Society 7, Pp. 237-51.

Harris, Geoff T. and Jarrett, Frank G. 1990. Educating Overseas Students in Australia: Who Benefits? Sydney, Australia: Allen and Unwin.

Hayden, Howard. 1967. 'Thailand'. Higher Education and Development in Southeast Asia Volume II, Country Profiles. UNESCO and the International Association of Universities, no page numbering in original.

Hayhoe, Ruth. 1996. 'the International Role of Japanese Universities'. Paper given at the 9th World Conference of Comparative Education, University of Sydney, 1-6 July, 1996.

and Yu, Yongling. 1996.

'Chinese Higher Learning- the Transition Process from Classical Knowledge Patterns 
to Modern Disciplines and Academic Structures'. Paper given at the 9th World Conference of Comparative Education, University of Sydney, 1-6 July, 1996.

Hicks, Frank. 1979. 'Crisis in the Legitimation of Educational Knowledge: a Case Study'. In Control and Knowledge: the Mediation of Power in Institutional and Educational Settings. Edited by Michael E. Pusey and RobertE. Young. Canberra, Australia: Australian National University Press.

Hinkson, John. 1991. Postmodernity: State and Education.

Geelong, Victoria, Australia: Deakin University Press.

Hofstede, Geert and Harris Bond, Michael. 1988. 'The Confucius Connection: From Cultural Roots to Economic Growth'. Organizational Dynamics 16(4), Pp. 5-21.

Honey, John. 1998. Language is Power:

Illich, Ivan and Verne, Etienne. 1981. Imprisoned in the Global Classroom. Second Edition. London, UK and New York, USA: Writers and Readers Publishing Co-operative Ltd.

Inthankamhaeng, Ranjuan. 2536. Floating the Garland of the Dhamma. In Thai. Bangkok, Thailand

Jackson, Peter a. 1988. Buddhadasa: A Buddhist
Thinker for the Modern World. Bangkok, Thailand: the Siam Society, Under Royal Patronage.

Jacobs, Norman. 1971.

Modernisation without Development: Thailand as an Asian Case Study. London, UK: Praeger Publishers.

James, Richard and Baldwin,

Gabrielle. 1999. Eleven

Practices of Effective Postgraduate Supervisors. Melbourne, Australia: University of Melbourne.

Kerr, Clark. 1964. the Uses of the University. Cambridge, Massachusetts, USA: Harvard University Press.

Ketudat, Sippanondha. 1973. 'A View of University Development in Thailand'. Reprinted in Education in Thailand: Some Thai Perspectives. Department of Health, Education and Welfare, USA, Pp. 93-105. Original Article in Thai in Journal of the National Education Council 4(4). Bangkok, Thailand, May 1969 , Pp. 1-18.

Kitchener, Karen S. and Brenner, Helene G. 1990. 'Wisdom and Reflexive Judgement: Knowing in the Face of Uncertainty'. In Wisdom: Its Nature, Origin, and Development. Edited by Robert J. Sternberg. Cambridge, UK: Cambridge University Press, Pp. 212-27. 
Kim, Thong Lay. 1996. 'The Changing Role of the University in Malaysia'. Paper given at the 9th World Conference of Comparative Education, University of Sydney, 1-6 July, 1996.

Knowles, Malcolm S. 1980. The Modern Practice of Adult Education: From Pedagogy to Andragogy. Chicago, USA: Follett Publishing Company.

Kobayashi, Tetsuya. 1986. 'the Internationalisation of Japanese Education'. Comparative Education 22(1), Pp. 65-71.

Kolb, David a. 1984. Experiential Learning: Experience as the Source of Learning and Development. New Jersey, USA: Prentice-Hall Inc.

Komin, Suntaree. 1992. Psychology of the Thai People: Values and Behavioural Patterns. Bangkok, Thailand: National Institute of Development Administration.

Kongkoy, Sayan. 1996. 'A Thai Student's Experience in Australia'. Paper Presented at 6 th International Congress of Women, Adelaide University, May, 1996.

Kristeva, Julia. 1977. 'A New Type of Intellectual: The Dissident'. Translated by Sean Hand. In The Kristeva Reader. Edited by Toril Moi. 1986. Oxford, UK: Basil Blackwell, pp. 292300 .
Lakshmana Rao, G. 1976. Overseas Students in Australia: Some Major Findings from a Nationwide Survey. Canberra, Australia: Australian National University Press.

1979. Brain Drain and Foreign Students. St. Lucia, Brisbane, Australia: University of Queensland Press.

Laureys, Godelieve. 1992. 'Mobility has Come to Stay: Management Strategies to Meet the Demands of Internationalisation in Higher Education'. Higher Education Management 4 (1), pp. 108-20.

Le Goff, Jacques. 1993. Intellectuals in the Middle Ages. Translated by Teresa Lavender Fagan. Cambridge, UK and Massachusetts, USA: Basil Blackwell.

Lee, Yumi and Ninnes, Peter. 1995.

'A Multilevel Global and

Cultural Critique of the

Diploma Disease'. Comparative Education Review 39(2), May, Pp. 169-77

Leeuwis, Cees, Long, Norman and Villarreal, Magdalena. 1990. 'Equivocations on Knowledge Systems Theory: an ActorOriented Critique'. Knowledge and Policy: The International Journal of Knowledge Transfer and Utilization 3(3), Fall, Pp. 19-27 
Lester, Robert C. 1973. Theravada

Buddhism in Southeast Asia.

Michigan, USA: Ann Arbor

Paperback, University of

Michigan Press.

Ma Rhea, Zane. 1992. Tablets from the Mountain...Hard Pills To

Swallow? Unpublished

Thesis, Flinders University of

South Australia, Australia.

1994. 'Secular

Postmodernity and Buddhist

Modernisation: Australia and

Thailand'. In Religion

Literature and the Arts.

Edited by Michael Griffith.

Sydney, Australia: Berget Pty.

Ltd., Pp. 340-6.

1995a. 'Changing

Manifestations of Wisdom and

Knowledge in Thailand'.

Prospects 24(4), December, Pp. 669-82.

1995b. 'From Gift to

Commodity: The

Transformation of the Higher

Education Relationship

between the Kingdom of

Thailand and Australia'. Paper

Presented at the Fourth

International Symposium on

The Role of Universities in

Developing Areas,

Proceedings Volume 1, Section

- 6A, 11-14 July, 1995,

Melbourne, RMIT.

1996. 'The Implications of

Changing Manifestations of

Wisdom and Knowledge for

Higher Education in Thailand'.

Paper given at the 9th World

Conference of Comparative

Education, University of
Sydney, 1-6 July, 1996.

. 1997a. 'University Knowledge

Exchange: Gift, Commodity

and Mutual Benefit'

Californian Sociologist 17/

18, Pp. 211-50.

1997b. 'Gift, Commodity and

Mutual Benefit: Analysing the

Transfer of University

Knowledge between Thailand

and Australia'. Higher

Education Policy: the

Quarterly Journal of the

International Association of

Universities, 10(2), Pp. 111-20.

2000. 'Contemporary

Knowledge Production and

Reproduction in Thai

Universities: Processes of

Adaptive Balancing' in RG

Teasdale, \& Z, Ma Rhea

(Eds.). 2000. Local

Knowledge and Wisdom in

Higher Education. UK:

Elsevier Pergamon, Pp. 209

235.

Forthcoming. 'The Economy of Ideas' in A. Quayson (Ed.)

Rethinking Postcoloniality.

UK: Blackwells.

MacKinnon, Valerie. 1995.

'Exporting Professional

Courses: Cultural and

Educational Implications'.

Paper presented at the Fourth

International Symposium on

The Role of Universities in

Developing Areas,

Proceedings Volume 1,

Section 4B, 11-14 July, 1995 ,

Melbourne, RMIT.

Mao Zedong. 1966. Where Do 
Approach to the Development of Critical Analysis in the University :

Correct Ideas Come From?

Peking, China: Foreign

Language Press.

1967. On Practice. Peking,

China: Foreign Language

Press.

1971. 'On Practice: On the

Relation between Knowledge

and Practice, between

Knowing and Doing'.

Selected Readings from the

Works of Mao Zedong.

Peking, China: Foreign

Language Press, Pp. 65-84.

Masemann, Vandra. 1990. 'Ways of

Knowing: Implications for

Comparative Education'.

Comparative Education

Review 34(4), Pp. 465-73.

1994. 'Educational Reform:

Impact of Indigenous Forms

of Knowledge'. In

International Encyclopaedia

of Education. Edited by

Torsten Hus?n and Neville

Postlethwaite. Pennsylvania, USA: Pergamon Press, Pp. 1848-51.

Mills, Colleen E. 1994. 'Culture, Com munication Style and Learning Style in Cross-Cultural Education: A Case for Preparatory Programmes for Students of Business'. Chulalongkorn Education

Review 1(2), Pp. 4-24.

Nabobo, Unaisi. 1994. 'Exploring

Yalomatua: Fijian Education and the Missing Link'.

Directions: Journal of Educational Studies, 16(1), Pp. 41-54. and Teasdale, Jennie. 1995.

'Education for Cultural

Identity'. Prospects 24(4),

December, Pp. 695-706.

Newman, John Henry. 1947. The

Idea of a University. New

York, USA: Longmans Green

and Company.

Nimmanhiminda, Sukich. 1970.

'Higher Education in

Thailand'. Journal of the

National Education Council.

Bangkok, Thailand, January, 1970, Pp. 62-93.

Nualnirun, Jariya. 1995. 'The

Humanities Ideal of

Universities in a Developing

Country: a Case Study of

Thailand'. Paper presented at

the Fourth International

Symposium on The Role of

Universities in Developing

Areas, Proceedings Volume 1, Section 2B, 11-14 July, 1995,

Melbourne, RMIT.

Nyanatiloka Mahathera. 1981. the

Word of the Buddha.

Sixteenth Edition. Kandy,

Ceylon: Buddhist Publication

Society.

1982. Path to Deliverance.

Fourth Edition. Kandy, Sri

Lanka: Buddhist Publication

Society.

1988. Buddhist Dictionary: a Manual of Buddhist Terms and Doctrines. Kandy, Sri

Lanka: Fourth Revised

Edition. Buddhist Publication

Society. 
Opper, Susan, Teichler, Ulrich and

Carlson, Jerry. 1990.

Impacts of Study Abroad

Programmes on Students and Graduates. Higher

Education Policy Series 11.

Two Volumes. London, UK:

Jesicca Kingsley Publishers.

Pongpisit, Pimchai. 1994.

'Internationalization of the

University of the Thai

Chamber of Commerce'.

Chulalongkorn Education

Review 2(1), Pp. 29-40.

Pookpakdi, Aphiphan et al. 1988.

Education for Development:

The Thai-Australian Prince

of Songkla University

Project. AIDAB Evaluation

Series No. 4, Canberra,

Australia: Australian

Government Publishing

Service.

Rizvi, Fazal. 1996. 'Malaysian

Students in Australian Higher

Education'. Paper given at

the 9th World Conference of

Comparative Education,

University of Sydney, 1-6 July, 1996.

Rosaldo, Renato. 1993. Culture and Truth: The Remaking of Social Analysis. London, UK:

Routledge.

Said, Edward. 1978. Orientalism. New York, USA: Panthenon Books.

1994a. Culture and

Imperialism. New York, USA and London, UK:

Vintage. 1994b. Representations of the Intellectual. London, UK:

Vintage.

Samuel, Moses. 1996.

'Internationalisation of Higher

Education in Malaysia.' Paper

given at the 9th World

Conference of Comparative

Education, University of Sydney,

1-6 July, 1996.

Scheler, Max. 1921. 'Universitat Und Volkshoschule'. In Sociologie

Des Volksbildungs-Wesens

(Sociology of the National

Education System). Edited by

Leopold V. Wiese. Munich and

Leipzig, Germany: Verlag Von

Dunker and Humbolt, Pp. 153-191.

1924. Probleme einer Soziologie

des Wissens (Problems of a

Sociology of Knowledge).

Translated by Manfred S. Frings.

1980. London, UK: Routledge

and Kegan Paul.

. 1960. 'the Sociology of

Knowledge: Formal Problems'.

Reprinted in the Sociology of

Knowledge: a Reader.

Edited by James E. Curtis and

John W Petras. 1970.

London, UK: Gerald

Duckworth and Co. Ltd., Pp.

170-86.

1963. 'On the Positivistic

Philosophy of the History of

Knowledge and Its Law of

Three Stages'. Reprinted in

the Sociology of

Knowledge: a Reader.

Edited by James E. Curtis and

John W Petras. 1970.

London, UK: Gerald 
Approach to the Development of Critical Analysis in the University:

Seidel, Hinrich. 1991.

'Internationalisation: a New Challenge for Universities'. Higher Education 21(3), Pp. 289-96.

Sethasathien, Unchalee. 1995. 'The Chiang Mai University's Effort to Develop Chiang Mai Community'. Paper presented at the Fourth International Symposium on The Role of Universities in Developing Areas, Proceedings Volume 1, Section 2B, 11-14 July, 1995, Melbourne, RMIT.

Shweder, Richard A. 1991. Thinking

Through Cultures:

Expeditions in Cultural Psychology. Cambridge, Massachusetts, USA and London, UK: Harvard University Press.

Simkin, Keith and Boonyanate, Nuangwong. 1996. 'Adapting Australian Universities to International Students'. Paper given at the 9th World Conference of Comparative Education, University of Sydney, 1-6 July, 1996.

Sinlarat, Paitoon. 1994. 'Successes and Failures of Faculty Development in Thai Universities'. Chulalongkorn Education Review 1(2), Pp. 46-64.

Sternberg, Robert J. 1990. Wisdom: Its Nature, Origins and Development. Cambridge, UK: Cambridge University Press.
Tapingkae, Amnuay. 1985. 'The Relevance of the American Education Model to Thailand'. In An ASEAN-American Dialogue: The Relevance of American Higher Education to Southeast Asia. Edited by Philip G. Altbach. Singapore: Regional Institute of Higher Education and Development.

Teasdale, G. R. 1982. 'Australian Educational Aid Relationships with South Pacific Countries'. Paper in Education and Development Seminar Series. Centre For Development Studies, Flinders University of South Australia, November 1982, Discussion Paper No. 4.

1995. 'Education and Culture: An Introduction'. Prospects 24(4), December, Pp. 587-92.

and Little, Angela. 1995. 'Open File: Culture and Education'. Prospects 24(4), December. Geneva, Switzerland: UNESCO and International Bureau of Education.

and Teasdale, J.I. 1992.

Voices in a Seashell:

Education, Culture and Identity. Suva, Fiji: UNESCO and University of the South Pacific.

1993. 'Culture and Schooling in Aboriginal Australia'. In International Perspectives on Culture and Schooling. Edited by E. Thomas. London, UK: University of 
London Institute of Education, Pp. 2-21.

Teasdale, RG \& Ma Rhea, Z. (Eds.). 2000. Local Knowledge and Wisdom in Higher Education UK,: Elsevier Pergamon.

Ternai, Prapaipit Chamsuksai and Ternai, Bela. 1995. 'Development of Joint Research Linkages between Thai and Western Universities'. Paper presented at the Fourth International Symposium on The Role of Universities in Developing Areas, Proceedings Volume 1, Section 6A, 11-14 July, 1995, Melbourne, RMIT.

Thaman, Konai Helu. 1995.

'Concepts of Learning,

Knowledge and Wisdom in Tonga, and Their Relevance to Modern Education'.

Prospects 24(4), December, Pp. 723-34.
Thanasuthipitak, T. and Ramingwong, T. 1995. 'Development of International Graduate Programs at Chiang Mai University: Case Studies of Direct Support for Development Agencies and Interaction between Universities in Developed and Developing Areas'. Paper presented at the Fourth International Symposium on the Role of Universities in Developing Areas, Proceedings Volume 1, Section 6D, 11-14 July, 1995, Melbourne, RMIT.

Wyatt, David K. 1994. 'Education and the Modernization of Thai Society'. In Studies in Thai History. Edited by David K. Wyatt. Chiang Mai, Thailand: Silkworm Books, P. 223-48. 